\title{
LAND USE IN THE AREAS AFFECTED BY GLIMEE-TYPE LANDSLIDES IN THE TRANSYLVANIAN PLAIN. CASE STUDIES: THE LANDSLIDES FROM APATIU, ARCHIUD, BOZIEȘ AND MĂLUȚ
}

\author{
V. V. POP'
}

\begin{abstract}
Land Use in the Areas Affected by Glimee-Type Landslides in the Transylvanian Plain. Case Studies: The Landslides from Apatiu, Archiud, Bozieș and Măluț. A special way of land utilisation in the Transylvanian Plain can be found in areas with glimee-type landslides. Their micro-relief drove people to resort to most various land use methods. From the numerous sites with glimee-type landslides in the Transylvanian Plain, this study focuses on the landslides from Apatiu, Archiud and Măluț. Pastures, hay meadows, orchards and vineyards are among the best represented categories of land use. Knowing the precise area occupied by these categories may offer a valuable insight about the economic importance of these plots of land. Furthermore, we have to stress that recently more and more glimee-type landslides have been included in Natura 2000 protected areas. Such actions help justify the increased attention that must be offered to these areas, economically, scientifically, but also as a tourist attraction.
\end{abstract}

Keywords: glimee-type landslides, land use, topo-climate, pedogenetic processes, Transylvanian Plain, agricultural reclaiming.

\section{INTRODUCTION}

The glimee-type landslides represent a true geographic puzzle considering the number of positive and negative relief forms that occur in such an area, the topo-climatic, hydrologic (including hydrogeology), vegetation, fauna and soil characteristics, as well as land use. Given its generally low economic potential, the geographical features of the relief on glimee-type landslides are very diverse, creating an extremely intricate micro-geographical pattern, under the combined influence of following factors: relief variety, slope orientation, groundwater, soil and vegetation characteristics, and human factors (Gârbacea, 2013).

\footnotetext{
1 Babeș-Bolyai University Cluj-Napoca, Faculty of Geography, 400006, Cluj-Napoca, Romania,
} e-mail: vassypop@gmail.com 
Generally, the relief bounds interdependently with the topo-climate, the soil properties and vegetation forms, thus influencing land use. Likewise, even a micro-relief may cause differences and discontinuities in the micro-topo-climate, in soils and plant communities, causing sudden changes in soil and plant repartition on the very same, relatively small hillside. A first differentiation occurring in glimee-type landslide sites is that between the warmer and dryer sunlit slopes (oriented toward south, south-west, and south-east), and the shaded slopes (oriented toward north, north-west, and north-east) (Resmeriță et al., 1968). Research carried out in the Transylvanian Plain found that on a south-oriented slope the maximal temperature at ground level reached $52^{\circ} \mathrm{C}$, while on the north-oriented slope it was just $27^{\circ} \mathrm{C}$, and also registered great rainfall differences between the two slopes (Bujoreanu, 1933, cited by Resmeriță et al., 1968). Under such circumstances, the biomass production will be bigger on the shaded slopes, while the sunlit ones will favour vineyard cultivation.

The uneven terrain created by these landslides shows some features unique to the Transylvanian Plain: hill fronts covered by 5-20\% with vegetation, landslides with xerophytic plants, depression alignments holding sometimes standing water, etc., causing a low meadow productivity in both, quantity but especially in quality (Resmeriță et al., 1968).

Likewise, the soils suffer a local replacement. If at regional level argillic chernozems and preluvisols are prevalent, at local level the diversity of geographic factors will result in a large variety of soil types. Consequently, on the scarp walls, given their higher gradient, pedogenetic processes are slower or even stopped by weathering factors, thus staying in the early stages of soil formation. On the earthflow masses, as a result of the mixed bedrock and the uneven slopes, soil forms differently at distances of even several centimeters (Chițu, 1975). In areas with glimee-type landslides there are often found hydromorphic soils, stagnosols, and pellicvertisols in the main depression alignment. On the elongated landslide toe slopes, consisting of clay sands with excess water, there are gleyic chernozems; on sand, sandstone and tuffs there are forming regosols. In secondary depressions there are forming coluvisols, carbonated, highly humificated soils. These types are seen as the best for local fertility classification, as they are not compacted, and the humus forms very thick layers (Gârbacea, 2013).

Topoclimatic, hydro-geologic and pedologic conditions affect not only the occurrence, evolution, and territorial distribution of phytocoenoses, but also their floristic structure. Thus, in the moist basins separating positive terrain forms, vegetation is hygrophilous, as in marsh regions (Carex, Juncus, Typha, Salix). The deeper the impermeable rock layer, the more diversified the phytocoenoses, with a further diversification of plant communities due to slope aspect (Resmeriță et al., 1968). Analysing the site from Apatiu, a variation in vegetation is visible for different 
slope aspects, with shaded hillsides frequently carrying common hawthorn (Crataegus monogyna), common dogwood (Cornus sanguinea), cornel cherry (Cornus mas), hazel (Coryllus avellana), hornbeam (Carpinus betulus), and even oak (Quercus robur), while sunnier slopes are more xerophilous in nature and are usually covered with Andropogon ischaemum (fig. 1).

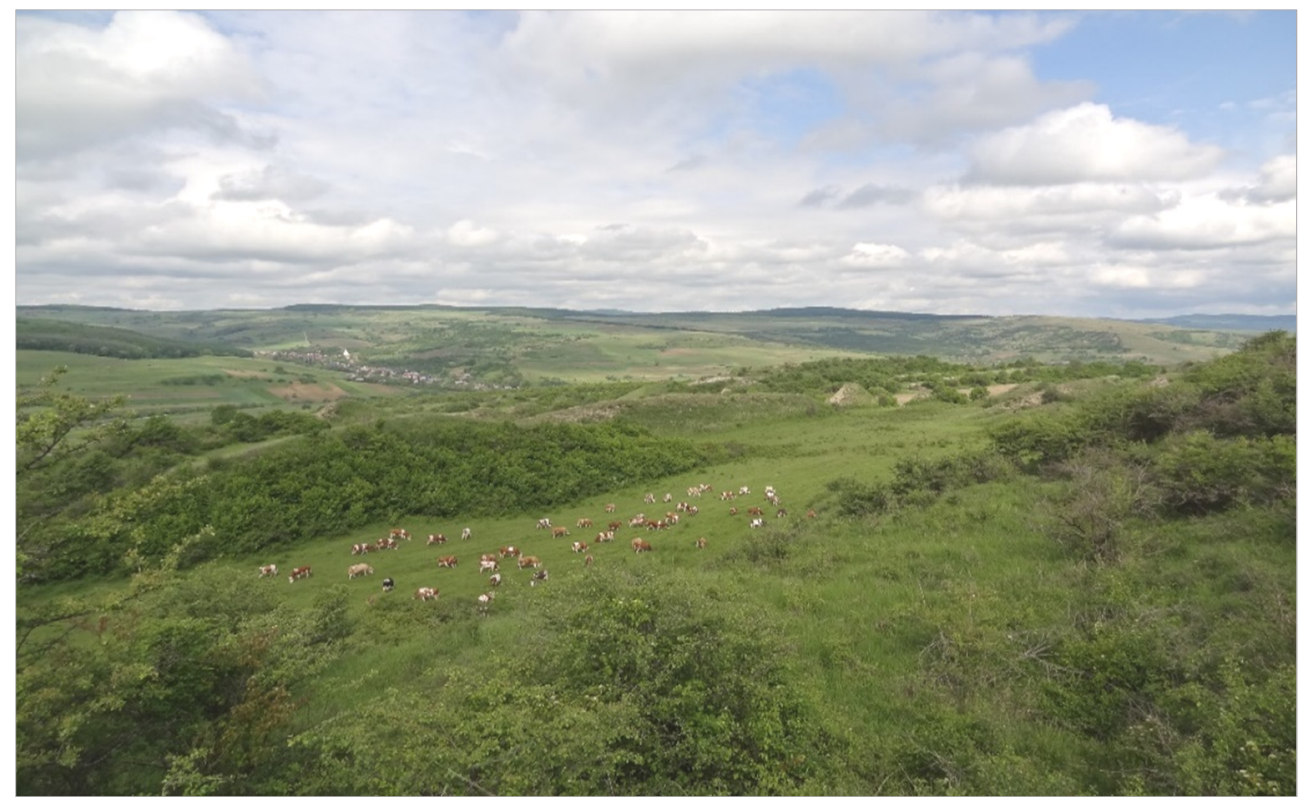

Fig. 1. Land cover differences due to slope orientation

The land use of areas with glimee-type landslides is different from one region to another. In the Hârtibaciu Plateau, for example, a solution to utilise them was to grow fruits on flattened earth masses (Grecu, 1992). At Corunca, they were used differently: those from the first row were planted with fruit trees and black pine (Pinus nigra); the second alignment, near the village, is occupied by fruit trees and vineyards, while in the village itself they grow vegetables and vine; cereals and potatoes are cultivated on the fourth and fifth rows (Irimuș, 1998a). Recent research on the utilisation of areas with glimee-type landslides supports the idea of including these terrains in natural protected areas, due to relict species from the post-glacial period, such as Astragalus excapus, as well as for landscape reasons due to their morphology (Roșianu et al., 2012). 


\section{RESEARCH TERRITORY}

The case studies are located in hydrographic basins of the $3^{\text {rd }}$ order in the Horton-Strahler system, with the exception of the landslide from Măluț, which lies in a $4^{\text {th }}$ order basin.

The Transylvanian Plain is a major unit of the Transylvanian Basin, located in its middle, being very visibly outlined by the bordering valleys: Someș rivers to the North, Racilor and Zăpodie valleys to the west, the Arieș-Mureș river system to the south, and the Șieu, Dipșa, Lunca and Luț river valleys to the east.

This region is considered to hold the majority of glimee-type landslides from the entire Transylvanian Basin. The research undertaken by Moldovan Monica and her team on glimee-type landslides in Transylvania mapped 480 sites, from which $59.2 \%$ are located in the Transylvanian Plain (Moldovan, 2012). Their high occurrence is linked to the alternation of sands with marl and clay in the Tortonian and Pliocene deposits (Ciupagea et al., 1970).

Geologically, the Transylva-

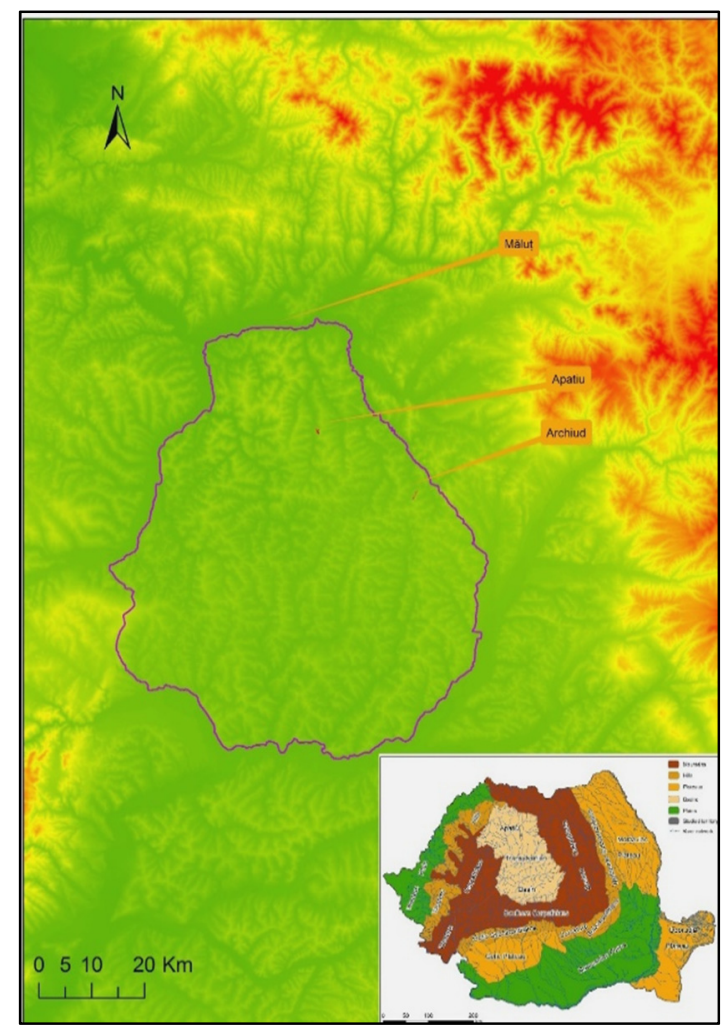

Fig. 2. Location of the studied landslides nian Plain is characterised mainly by Tortonian deposits, with two distinct facies: a littoral one, with conglomerates and sandstone, and a bathyal facies, with sands and marl clay (Săndulache et al., 1964), while Pliocene deposits occur mainly in the south-western part. The Tortonian layer usually comprises violet-grey marl with sand intercalations, besides which there occur loose sandstone, and frequently alternating, thin layers of sands and sand marl. Within these Tortonian layers there are intercalations of dacitic tuff, whose thickness ranges from a few millimetres to several meters (Vancea, 1960). 
Regarding land use in the Transylvanian Plain, over $90 \%$ is agricultural land, of which $60 \%$ is arable land and $30 \%$ pastures and hay meadows, while forests cover approximately 9\%, with significant regional disparities (Pop, 2001). The importance of utilising the areas with glimee-type landslides resides exactly in their high occurrence rate in this landform unit.

\section{METHODOLOGY AND DATA USED}

Regarding the methods applied, we conducted topographical surveys on site using a GPS Trimble R4 device running GNSS technology. Following the measurements, we used the ArcGIS application to draw the geomorphological maps of sites with glimee-type landslides. The areas showing each land use category were extracted from the physical blocks of each plot registered at APIA (the Agricultural Payment and Intervention Agency). All these elements were superimposed on 2012 aerial images.

\section{RESULTS}

\subsection{The landslide from Apatiu}

The landslide site is located within the administrative borders of Apatiu, on the right slope of the Apatiu Valley, in the Meleș Valley Basin, a tributary of Someșul Mare River.

In cross section, the terrain shows three sectors, with distinct morphologic, morphometric, and functional features: the scarp, the flowage zone, and the toe. The main scarp front has a length of $800 \mathrm{~m}$ and a fall $25-50 \mathrm{~m}$ in height. The scarp front is still active and is affected by new glimee-type landslides that bulge at the base of the front, making the transition to the depression alignment.

These new landslides are in their incipient phase and are much smaller, given present-day climatic conditions. The glimee ridges complex lies at the bottom of the slump zone, forming five parallel rows that started to fall apart even during the slide. The ridges have various sizes and are separated by microdepressions, some of which are larger, while others are not so visible. The largest ridges are those from the $2^{\text {nd }}$ and $3^{\text {rd }}$ rows, showing relative heights of about 20 $25 \mathrm{~m}$. Presently, the first row is affected by a strong re-fragmentation (fig. 3), resulting in a new landslide mass of the same length separated from the originating body by a 3-4 m deep trench, indicating a new depression alignment (fig. 3) (see also Pop, 2015). 


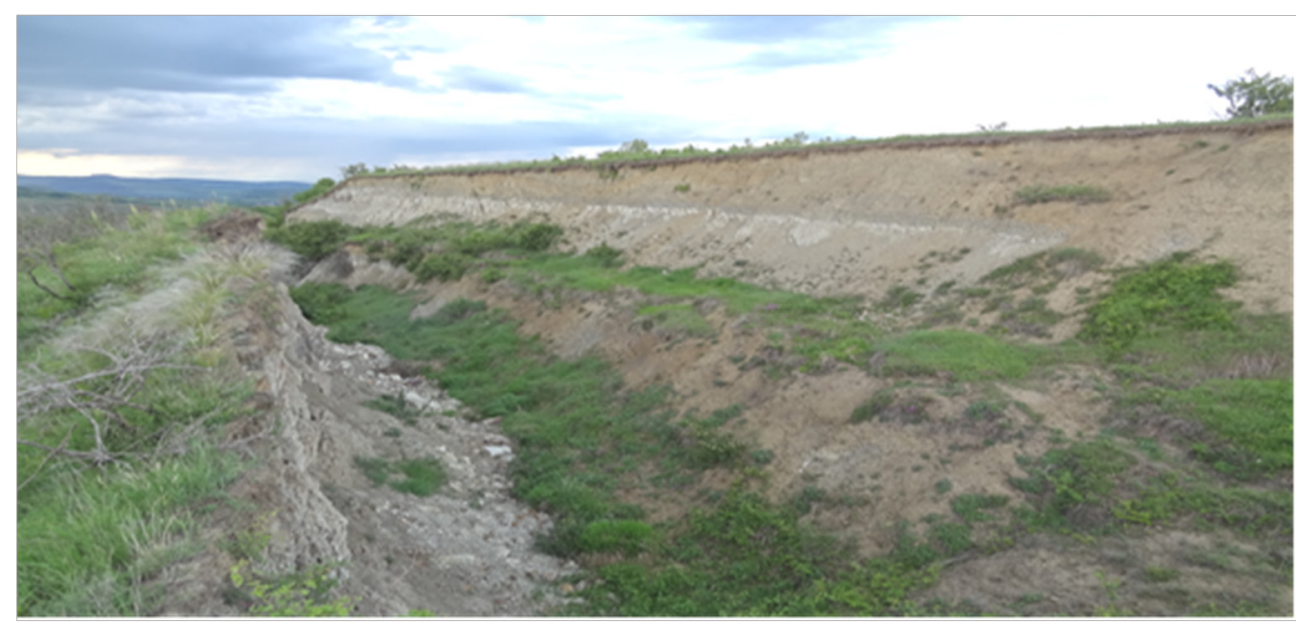

Fig. 3. The newly formed depression alignment

Regarding the land use of the site, there is an important agricultural reclamation, with permanent pastures still prevailing (fig. 4). The spatial distribution of these pastures is effected by the great extent of transversal depressions and of humid areas in horizontal areas. The prevalence of permanent pastures to the detriment of arable land can be explained simply by the fact that it is not feasible to cultivate small, mostly low-productive parcels. Another explanation could be the distance to the village.

Due to relatively high altitude differences between the transversal depressions and the conical forms with steep slopes, ridges and scarps, these terrains are considered to be non-productive (fig. 4). It must be mentioned that the current land use mode

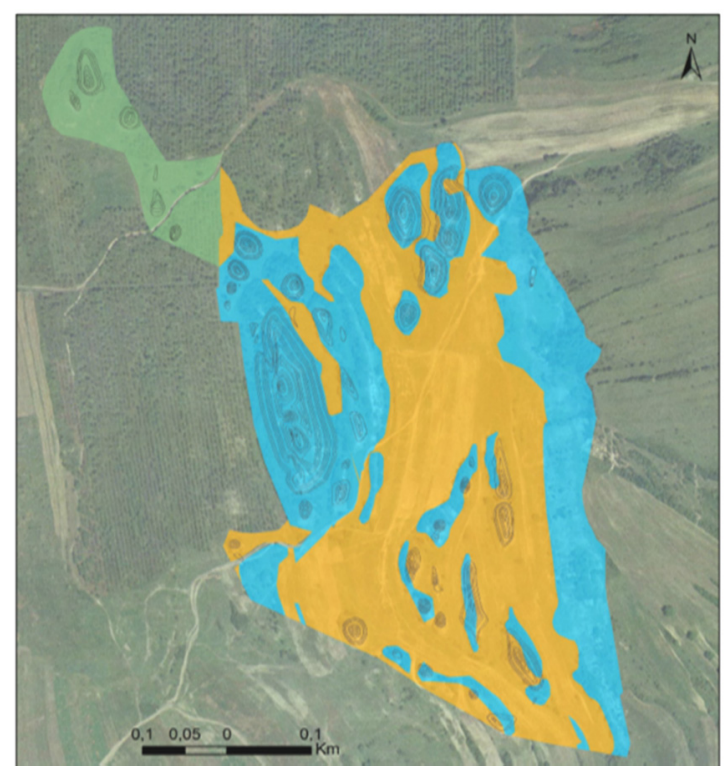

Fig. 4. Land use within the site with glimeetype landslides from Apatiu, according to APIA data, 2015 (green: permanent crops, others than vineyards, orchards, etc.; blue: non-productive land, covered with reed and bulrush, or marsh vegetation; orange: permanent pastures) 
within this landslide site is implemented according to the annual inventory of the Agricultural Payment and Intervention Agency (APIA), in this case for the year 2015.

It is interesting to observe the comparison between the land use before and after the year 1989. Until 1989, the land was cultivated on large parcels through Agricultural Production Cooperatives (APCs), and most of this landslide site was classified, according to the agricultural registry from 1989, as non-productive land, being used as pasture. The frontal side of the landslide was levelled in 1984 and a plum orchard was cultivated on its base, including the higher ridges in the plantation (fig. 4). After 1989, with the dissolution of the APCs and the privatisation of the land, there occurs a change in land use, with some of the transversal depressions being transformed in arable land with a crop rotation system, the main cultures being corn, wheat, and potatoes.

The agricultural reclamation rate in the landslide site is shown in figure 5. From a total of approximately 42 hectares, $42.13 \%$ is non-productive land, $49.42 \%$ are permanent pastures, and a small part $-8.44 \%$ - is cultivated. This distribution is due to a relatively large number of ridges with a high drop toward the depressions and steep slopes.

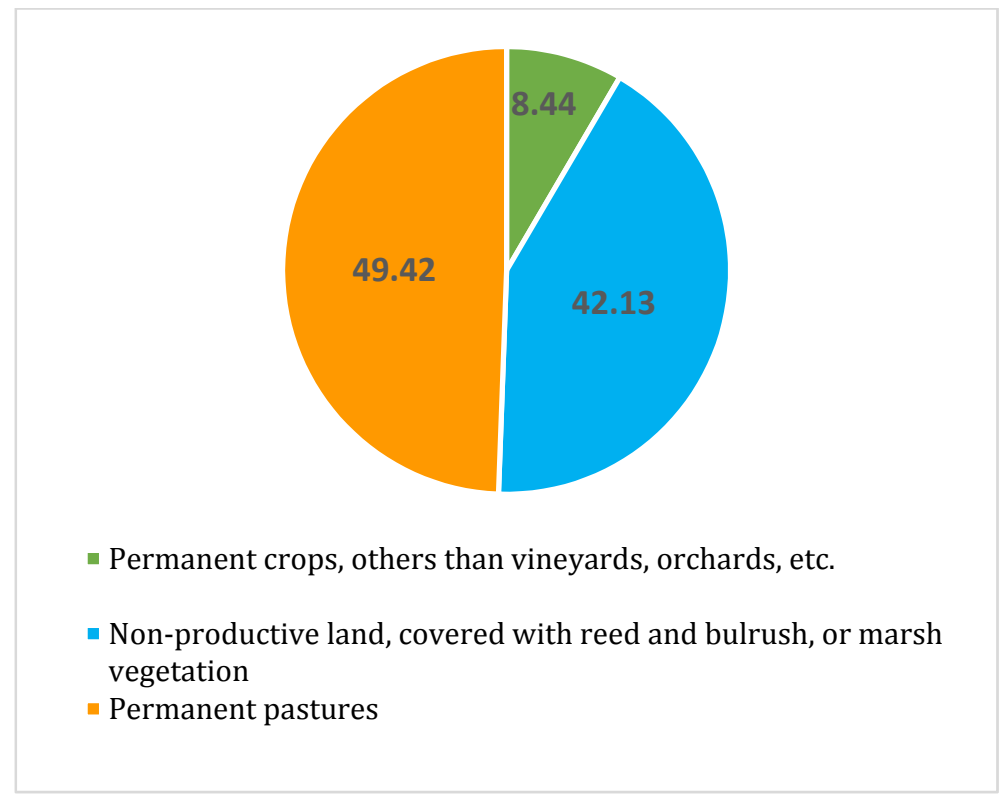

Fig. 5. Agricultural reclamation rate and land use of the glimee-type landslide from Apatiu 


\subsection{The landslide from Archiud}

The glimee-type landslide from Archiud is located to the east of the village, in area called „La Ciurgău”. Administratively, Archiud is part of Teaca commune, Bistrița-Năsăud County, in the Dipșa Valley basin.

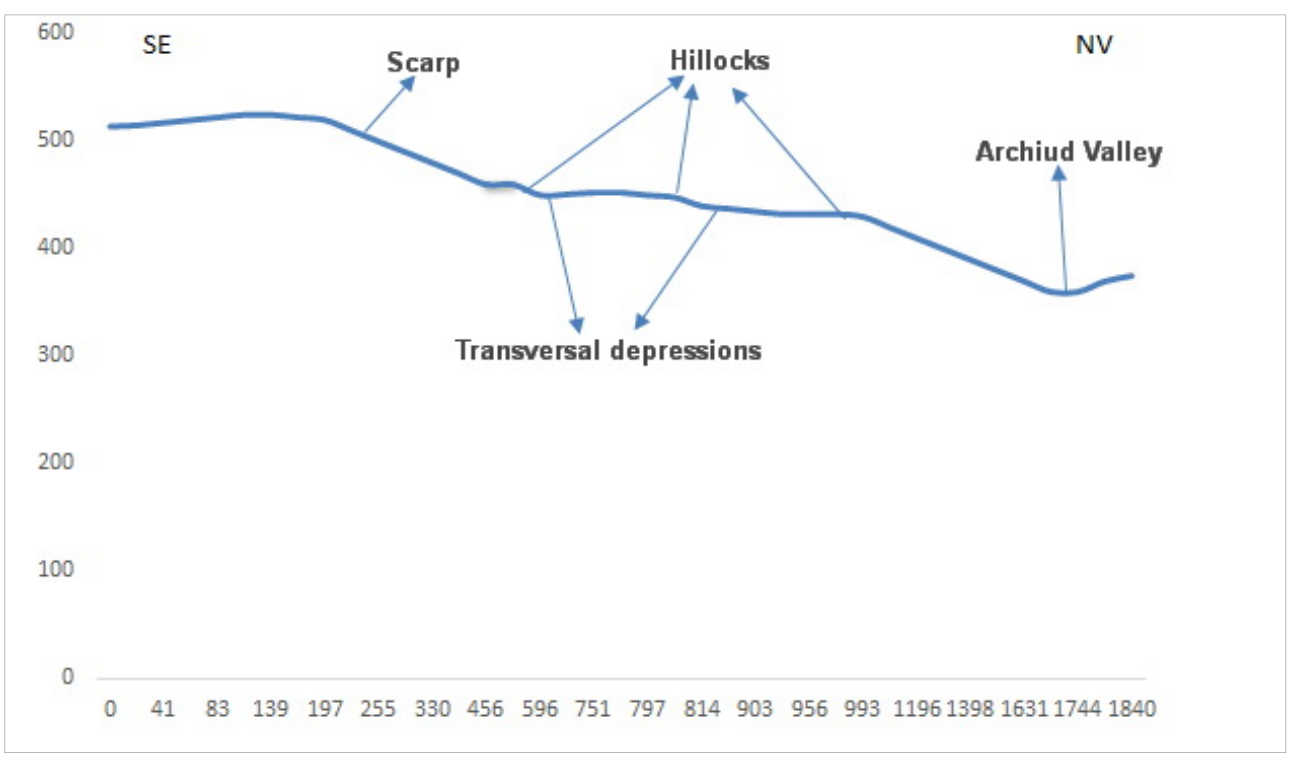

Fig. 6. Profile of the landslide from Archiud

The landslide comprises a forested fault scarp of $1.7 \mathrm{~km}$ in length, three hillock alignments parallel to the scarp, and very visible transversal depressions (fig. 6). The total area affected by landslides covers over 98.5 hectares.

The scarp lies at approximately $500 \mathrm{~m}$ in a watershed region. It has a drop of sometimes 45-50 m. Its surface is affected by rain wash, gully erosion, and falls, processes that are amplified by massive deforestation on the hillside (fig. 7).

The landslide mass shows three rows of hillocks, extending parallel to the scarp and the transversal depressions. Their height drops from the scarp towards the front, with the highest being those from the last landslide alignment. The latter appears as a long range of about $1080 \mathrm{~m}$ and a drop of 10-12 m towards the depressions (fig. 8). 


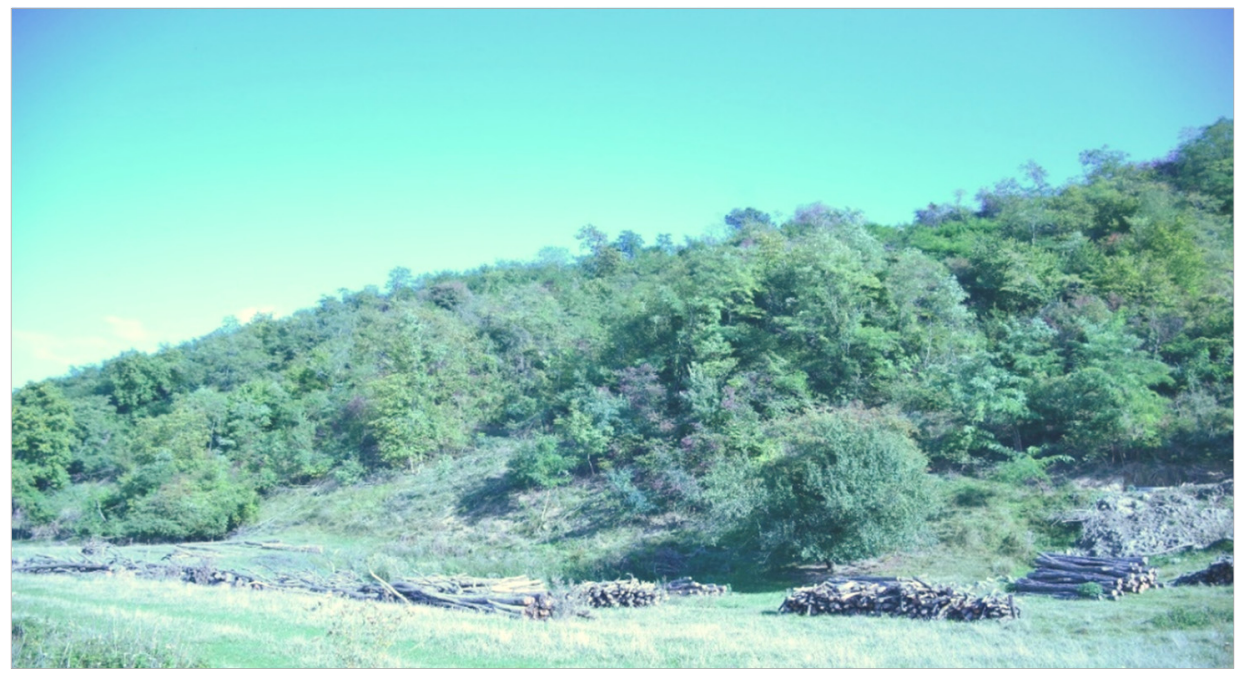

Fig. 7. The scarp of the landslide from Archiud, showing signs of deforestation

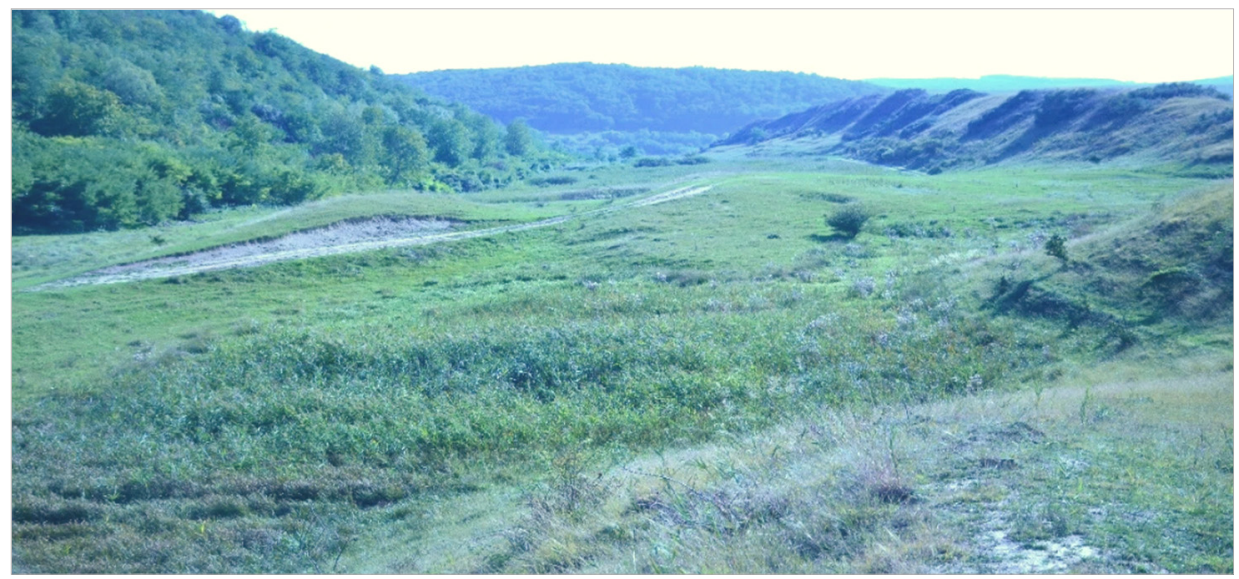

Fig. 8. Uniform hillock alignment and transversal depression

The other rows are more fragmented and smaller, disappearing towards the front of the landslide. If the landslide as a whole is in a clear state of equilibrium, that is not the case of the hillocks, with dynamic morphological processes, such as falls, gully erosion, rain wash, and radial erosion, that are modelling these relief forms (fig. 9). Most hillocks are covered with grass and clusters of dog-rose (Rosa canina), blackthorn (Prunus spinosa), and sea-buckthorn (Hippophae rhamnoides), some of them showing on their southern slopes vineyards, nowadays mostly abandoned (Gârbacea, 2013). 


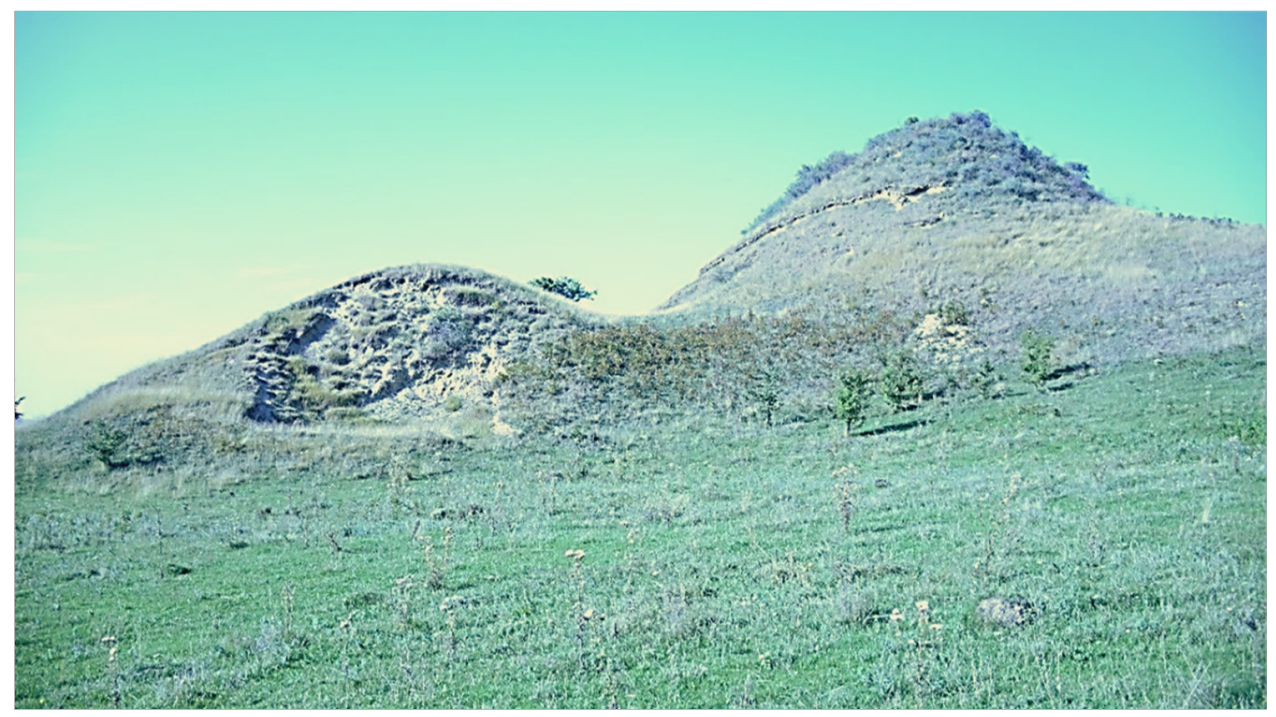

Fig. 9. Present-day erosion of the hillocks

Between the scarp and the hillocks there are the transversal depressions, the first of them situated between the last ridge and the scarp gradually increasing in width from $40 \mathrm{~m}$ at the east end to $95 \mathrm{~m}$ in the west, with a small incline from NE to SW. It is used as a pasture and at its contact with the hillock range there are spheroid Tortonian sarsen stones (fig. 10).

The width of the other depressions increases from $20-40 \mathrm{~m}$ in the east to $115-140 \mathrm{~m}$ in the west. A part of these depressions are cultivated with corn, wheat and alfalfa (Medicago sativa), some parts as hay meadows and pastures, while lower hillocks are used to grow fruits (mostly plume) and wine (fig. 11). At the west end of the site, the depressions are occupied by farms, that climb to the top of the hillocks. Due to their geological structure (clay, marl, and sands), some hillocks are used as source for building material (fig. 11).

Analysing the 1:5000 scaled topographical maps of the region we can learn that, prior to 1989 , the most part of the site was used as pasture and hay meadow, a fact supported by the presence of three sheepfolds at the east end of the site, while the arable land extended in the vicinity of the village (fig. 12a).

Changes in land use are due to re-privatisation following the dissolution of the APCs after 1989, that triggered an expansion of arable land, a part of the pastures and hay meadows being cultivated with corn and wheat, as the sheepfolds become gradually deserted and the vineyards are increasingly ignored. 


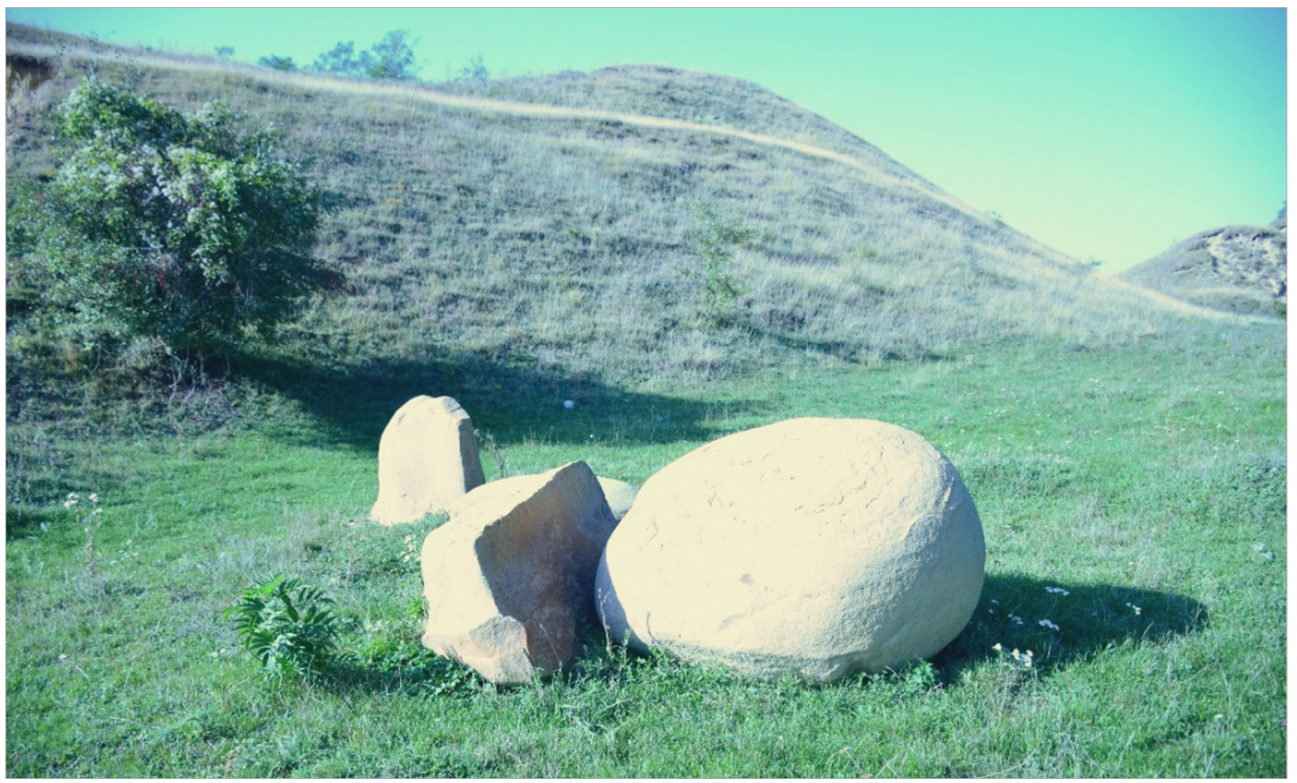

Fig. 10. Tortonian spheroid formations

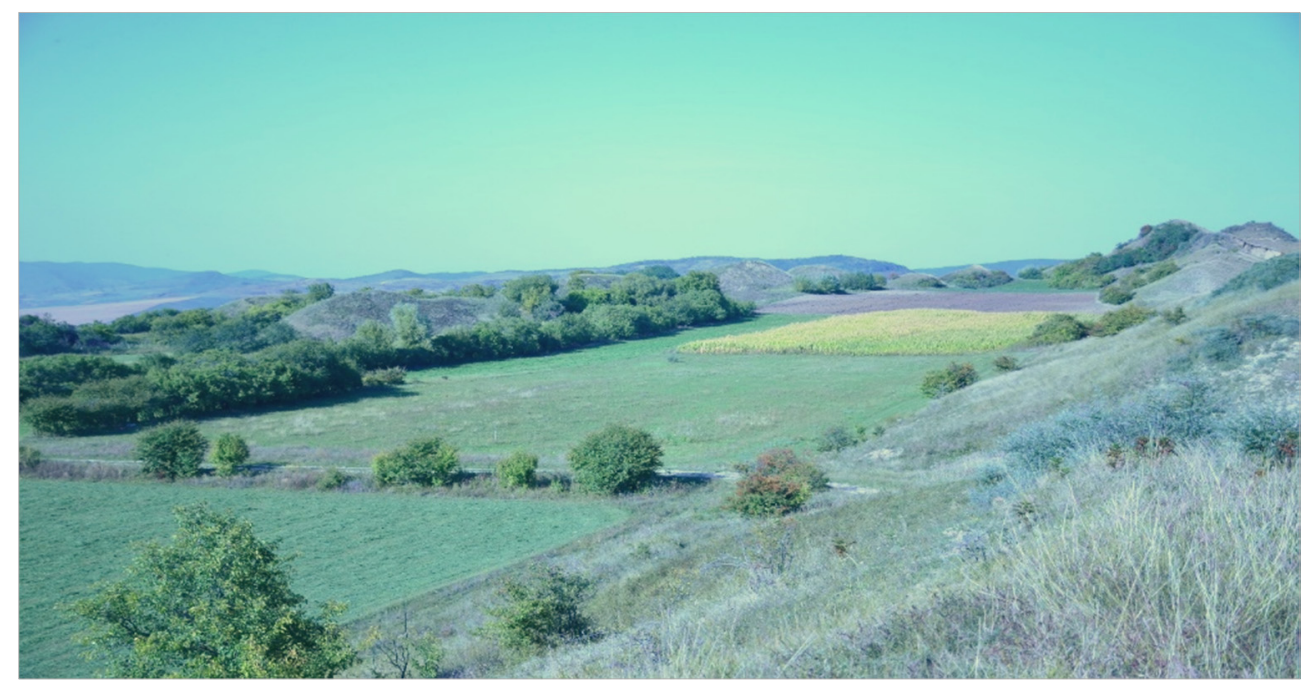

Fig. 11. Complex land use of the glimee-type landslide site 
At the present time (2015) the land use is showing signs of a return to its pre-1989 state, excepting the sheepfolds, due to population decrease and ageing in the village; high agricultural costs; and no viability of cultivating small land parcels. From the total area of 90 hectares, 54.06\% are used as pastures, $27.5 \%$ are non-productive, $1.09 \%$ is arable land, $0.91 \%$ are roads, and $0.55 \%$ are covered by farms and buildings (fig. 12b).
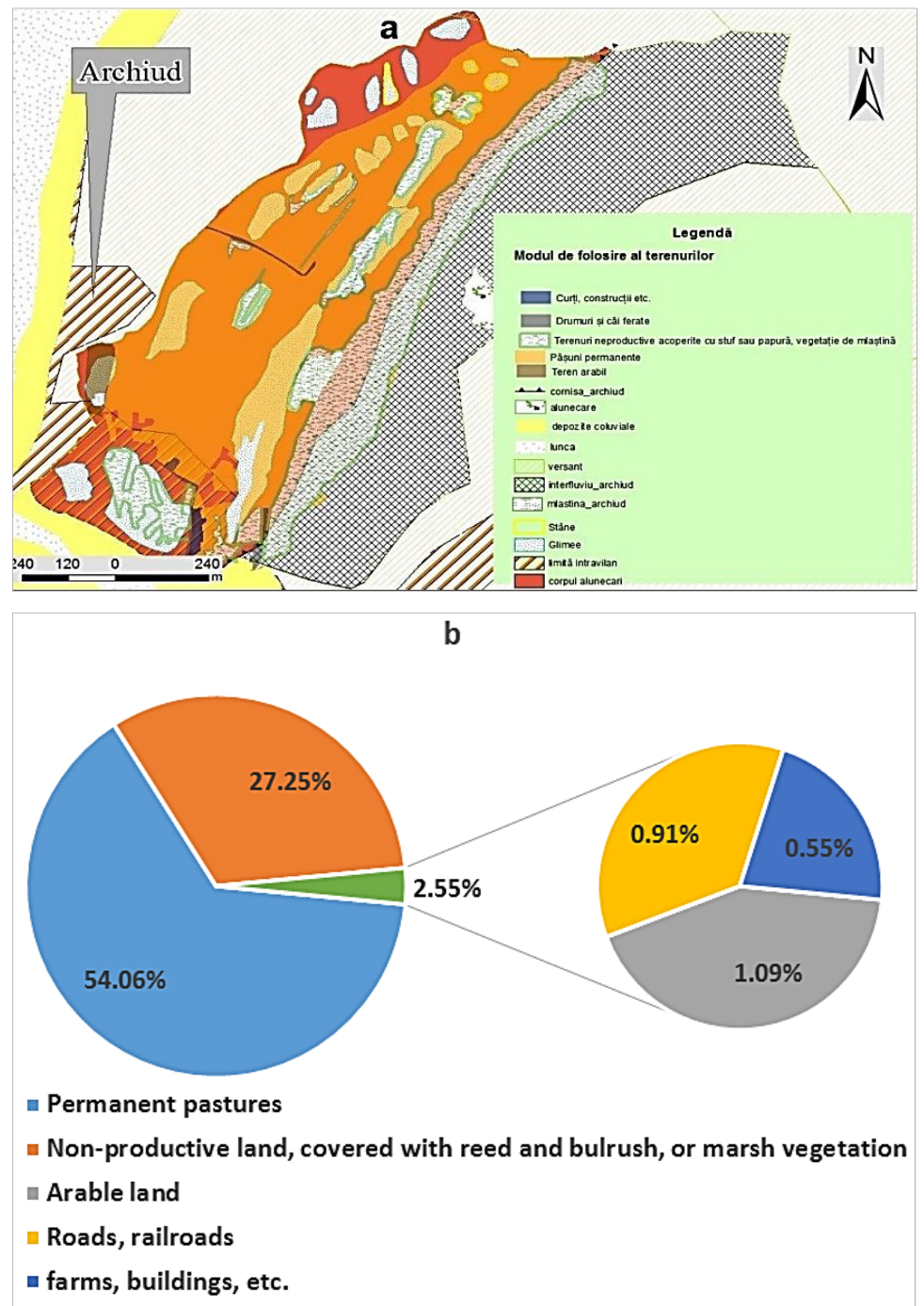

Fig. 12. Land use within the glimee-type landslide from Archiud, according to data from APIA, 2015 (a); agricultural reclamation rate in the site from Archiud (b) 


\subsection{The landslide from Mălut}

The landslide area is known by the locals as "the giants' graves" and is situated on the southern hillside of the Ungurașu and Cireșoaia Hills, in the region called „La Strigăi”, south-west from Măluț, in the Someșul Mare Valley. Being positioned on a monocline structure with strata falling from south to north, the landslide is a consequent one, formed through translational processes. Its profile shows three sectors with distinct morphologic, morphometric, and functional characteristics: the secondary scarp, the hillock complex, and the front of the earthflow.

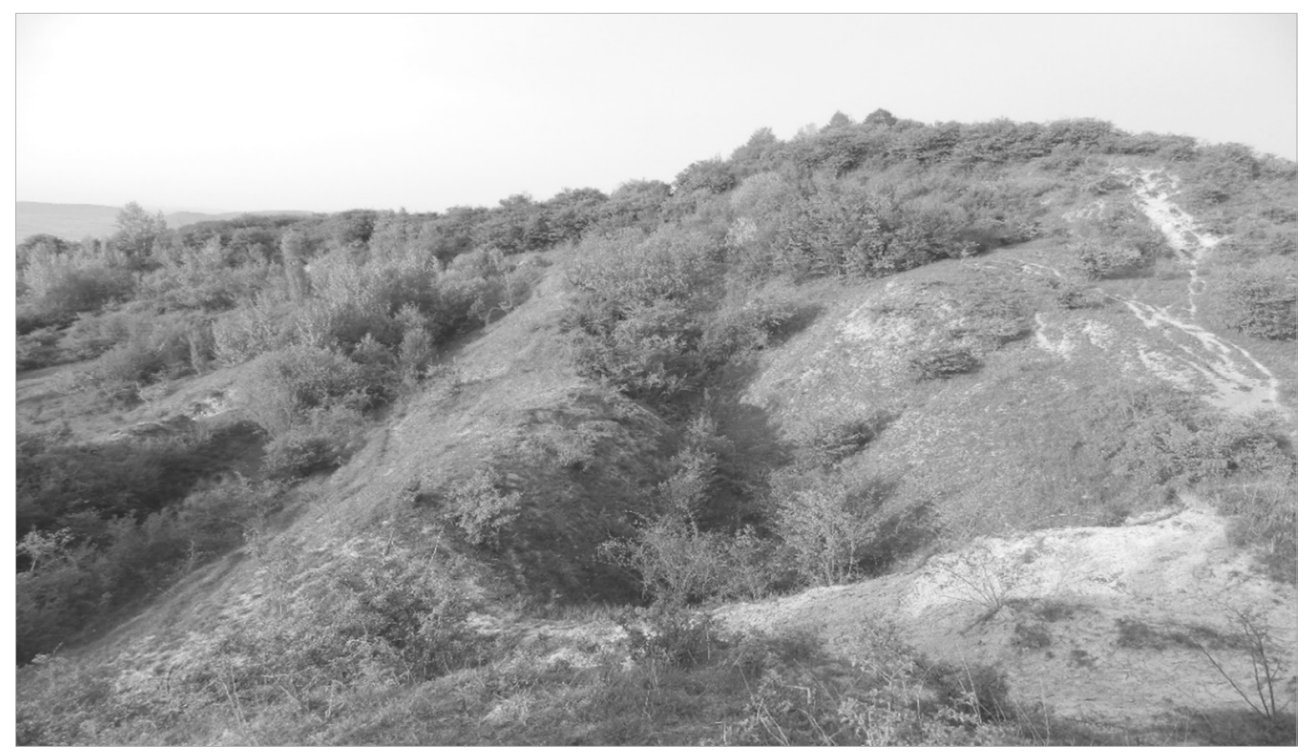

Fig. 13. The secondary scarp with hillock rows and transversal depressions

The secondary scarp is a $200 \mathrm{~m}$ long, L-shaped fault (fig. 13). On much of its surface, the stratification of the Tortonian deposits, with their northward incline, is visible. In longitudinal section, the watershed extends as a saddle between 382 and $380 \mathrm{~m}$, respectively (fig. 14). This fact gives us reason to conclude that the landslide developed in two stages, the first giving birth to the hillocks in the first row, right behind the front of the landslide, while in the second stage, the hillocks beneath the secondary scarp were formed. During the second stage, a main scarp still existed, but is nowadays visible only as an anticline. 


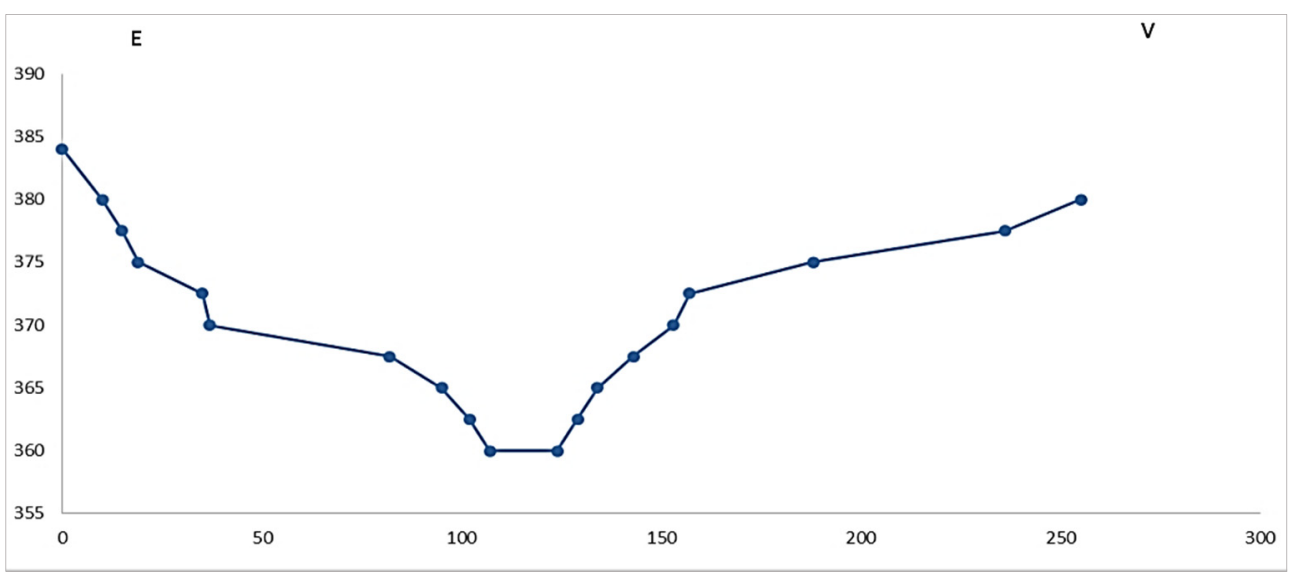

Fig. 14. Longitudinal section of the watershed

The transition from the secondary scarp to the hillock rows is made through a very narrow depression alignment (fig. 13), where traces of the existence of a small, now closed, pond are still visible. Its place is indicated by reed and the puddles that form during rainy periods. Compared to this alignment, the microdepressions between the hillock ridges are deeper and larger.

The glimee rows complex formed by the landslide comprises two parallel alignments of compact ridges and several compact, randomly placed hillocks that started to already erode during the slide. Although some of them appear currently isolated, this is due later rain wash, ridging, mudflow and other erosional processes.

Most of the hillocks are covered with grass, and shrubs of common hawthorn (Crataegus monogyna), dog-rose (Rosa canina), and blackthorn (Prunus spinosa). There is also wildlife represented by birds such as pheasant, mammals like wild boar, roebuck, rabbit and fox, and frogs and lizards in wet areas.

The largest hillocks are those within the two alignments, with relative altitudes of 5-10 meters. Presently, the second row is affected by rain wash and is fragmented in two parts separated by a niche with an alluvial fan at its base. On some hillocks there can be seen small ruptures that, in time, will fragment the ridges. Because of their shape, these forms are known in local toponymy as giants' graves.

The front of the landslide is represented by the first ridge, that ends in a rounded toe over the hillside. It is also possible that human activity contributed to its flattened shape. 
Regarding the land use in this landslide area, its entire surface is classified by APIA as non-productive land, covered with reed and bulrush, and only occasionally used as pasture (fig. 15). Analysing the 1:5000 scaled topographical maps, 1984 edition, it shows that in that period most of the landslide site was still non-productive, with pastures and orchards extending in its proximity.

The low land use rate within this landslide, as compared with the first two case studies, can be explained by the fact that the village is located in the floodplain and on the terraces of the Someșul Mare River, thus in plain areas with high agricultural potential, and also by the greater distance from the village, of approximately $2 \mathrm{~km}$.

\section{CONCLUSIONS}

Following the field research in the area of the three glimee-type landslide sites, we can conclude that there are landslides that are primary used as pastures (Măluț), or that have a more complex usage (arable land, pastures, fruit and vine growing, etc). There are such landslides with high agricultural utilisation (Archiud and Apatiu), or landslides with no significant agri-

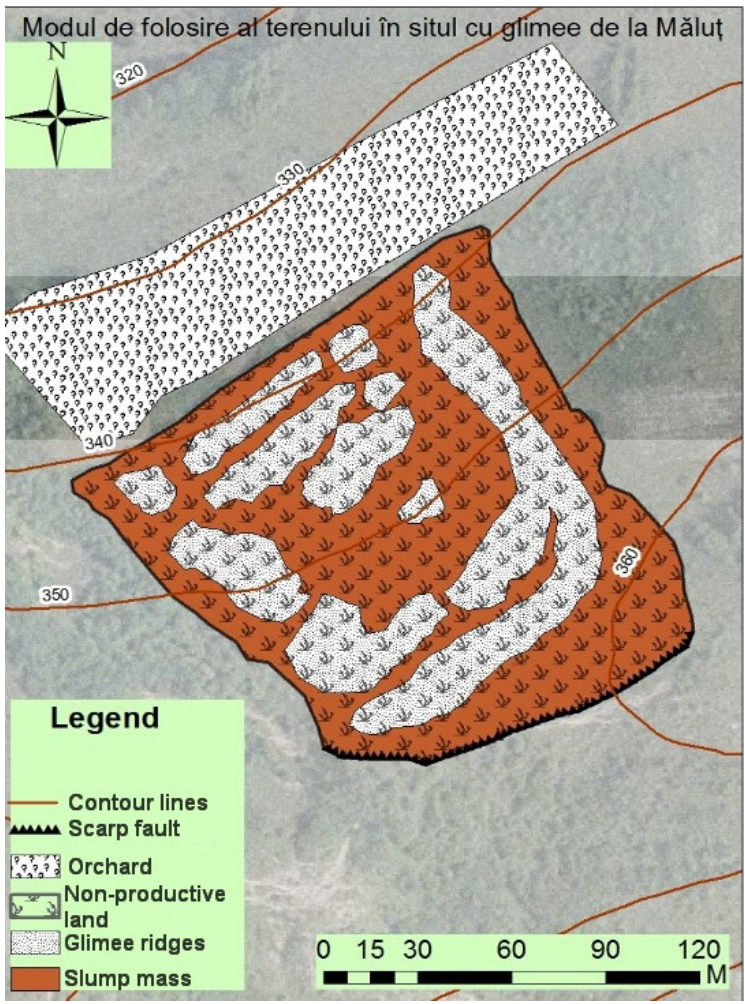

Fig. 15. Land use of the landslide from Măluț, according to data from APIA, 2015 culture (Măluț) except for occasional grazing. However, the most parts of glimee-type landslides are used as pastures. The land use and agricultural reclamation rate also depends on their distance to the nearest village. Before 1989, land use was conditioned by the form of land ownership, namely collective property of the APCs, where terrain cultivation was done on large areas, and landslides, with their small area, had been catalogued as non-productive and thus used as pastures. As land once again became private after 1989, there starts a complex agricultural reclamation of the glimee-type landslides, with a significant part of their area gaining agricultural usefulness. 


\section{REFERENCES}

1. Chițu, C. (1975). Relieful și solurile României, Edit. Scrisul Românesc, Craiova.

2. Ciupagea, D.T., Paucă, M., Ichim, T. (1970). Geologia Depresiunii Transilvaniei, Edit. Academiei Republicii Socialiste România, București.

3. Gârbacea V. (2013). Relieful de glimee, Edit. Presa Universitară Clujeană, Cluj-Napoca.

4. Grecu, Florina (1983). Alunecările de la Movile, Ocrot. nat. med. inconj., 27, 2.

5. Grecu, Florina (1992). Bazinul Hârtibaciului, Edit. Academiei, București.

6. Irimuș, I.A. (1998a). Alunecările de teren de la Corunca și implicațiile în organizarea spațiului geografic, An. Univ. „Dimitrie Cantemir”, Șt. Socio umane, II.

7. Jakab, S. (1972). Observații pedogeografice și pedomorfogenetice în Câmpia Transilvaniei, Șt. Sol., X, 3.

8. Moldovan, Monica (2012). Glimeele din Transilvania, PhD thesis, Cluj-Napoca.

9. Pop, V.V. (2015). Landslides from Apatiu, Meles Basin (Transylvanian Plain), Revista de Geomorfologie, 17, București.

10. Resmeriță, I., Csuros, Șt., Spârchez, Z. (1968). Vegetația, ecologia și potențialul productiv pe versanții din Podișul Transilvaniei, Edit. Academiei, București.

11. Resmeriță, I. (1971). Rezervația botanică de la Suatu, Ocr. Nat., 15, 2, București.

12. Săndulache, Al., Diaconeasa Băluţă M., Beju, D. (1964). Contribuţii la studiul originii lacurilor dulci din Câmpia Transilvaniei, Cluj.

13. Șoneriu, I. (1973). Aspecte ale valorificării agricole și silvice a terenurilor afectate de alunecări din partea central estică a Podișului Târnavelor.

14. Vancea, A. (1960). Neogenul din Bazinul Transilvaniei, Edit. Academiei Republicii Populare Române, București. 